\title{
Correction: Top 50 most-cited articles in medicine and science in football
}

Brito J, Nassis GP, Seabra AT, et al. Top 50 most-cited articles in medicine and science in football. BMJ Open Sport Exerc Med 2018;4:e000388. doi: 10.1136/bmjsem-2018-000388

The authors want to alert readers to the following two errors identified in the published version.

In the Results section, the second last sentence of the last paragraph, should read as: "Additionally, a clustered-network with 18 vertices of coauthorship collaborations in the top 50 is presented in figure 4"

Also, the caption of figure 4, has been modified to "Clustered network with 18 vertices of coauthorship collaborations in the top 50 most-cited articles in medicine and science in football."

Open access This is an open access article distributed in accordance with the Creative Commons Attribution Non Commercial (CC BY-NC 4.0) license, which permits others to distribute, remix, adapt, build upon this work non-commercially, and license their derivative works on different terms, provided the original work is properly cited, appropriate credit is given, any changes made indicated, and the use is non-commercial. See: http://creativecommons.org/licenses/by-nc/4.0/

(C) Author(s) (or their employer(s)) 2018. Re-use permitted under CC BY-NC. No commercial re-use. See rights and permissions. Published by BMJ.

BMJ Open Sport Exerc Med 2018;4:e00388corr1. doi:10.1136/bmjsem-2018-000388corr1

Check for updates 